\title{
Influence of type and concentration of sugars, supplemented with 8-hydroxyquinoline sulphate, on the vase life of waxflower
}

\author{
Cao D. Dung ${ }^{1 *}$, Kevin Seaton ${ }^{2}$, Zora Singh ${ }^{3}$ \\ ${ }^{1}$ Potato, Vegetable and Flower Research Center \\ Thai phien village, Ward 12, Da Lat, Lam Dong, Vietnam \\ ${ }^{2}$ Department of Agriculture and Food, Western Australia \\ 3 Baron-Hay Court, South Perth, WA 6151, Australia \\ ${ }^{3}$ Department of Environment and Agriculture \\ Curtin University \\ Kent Street, Bentley, Perth, WA 6102, Australia
}

\begin{abstract}
A study was conducted to test the effect of $58.5 \mathrm{mM}$ maltose, glucose, fructose, galactose and sucrose, and sucrose concentrations of 14.6, 29.2, 58.5 and $117.0 \mathrm{mM}$ supplemented with $200 \mathrm{mg} \mathrm{L}^{-1} 8$-hydroxyquinoline sulphate (HQS) on the vase life and stem fresh weight changes in waxflower (Chamelaucium Desf.). The effect of the interaction between sucrose and HQS concentrations on the vase life of the cultivar 'Alba' was also investigated. All the types of exogenous sugar significantly increased the vase life of flowers, but decreased the vase life of leaves of waxflower cultivars compared with the deionized water controls, except the leaves of 'Lady Stephanie', 'Purple Pride' and 'Mullering Brook'. The flower vase life of almost all the cultivars treated with sucrose was not significantly different from the life of the cultivars kept in fructose and glucose, except 'Laura Mae Pearl', whose flower vase life in sucrose was significantly lower (9.7\%) than in fructose. By contrast, the vase life of flowers of the cultivars treated with sucrose was longer than of those in maltose and galactose. At sucrose concentrations of up to $117.0 \mathrm{mM}$ coupled with $200 \mathrm{mg} \mathrm{L}^{-1} \mathrm{HQS}$, the flower vase life of six out of eight cultivars significantly increased, except in 'Laura Mae Pearl' and 'Mullering Brook', whose flower vase life was maximized at the concentrations of 29.2 and $58.5 \mathrm{mM}$ respectively, while the vase life of their leaves decreased. Sucrose concentrations from 14.6 to $29.2 \mathrm{mM}$ coupled with $50 \mathrm{mg} \mathrm{L}^{-1} \mathrm{HQS}$ maximized vase life for both the flowers and leaves of 'Alba'. Cultivars with a longer vase life of flowers maintained stem fresh weight above the initial stem fresh weight longer.
\end{abstract}

Key words: Chamelaucium, fresh weight, HQS, sugar types, vase life

\section{INTRODUCTION}

Improvement of the vase life of cut flowers by supplying sugar in the vase solution has been widely reported (Nichols 1973, van Doorn 2001, Arrom and Munné-Bosch 2012). The demand of cut flowers for carbohydrates is mainly satisfied by the application of exogenous sugar (Stephens et al. 2011) because cut flowers have a reduced ability to conduct photosynthesis after detachment from the plant (van Staden 1995). The vase life of cut flowers has been correlated with the sugar

\footnotetext{
*Corresponding author.

Tel.: +84914051004;

e-mail: caodinhdung2003@yahoo.com (C.D. Dung).
} 
content of flowers, with a higher sugar content promoting a longer vase life (Holly 1963). Adding sucrose to vase solutions or pulsing in higher sugar concentrations extended the longevity of cut Tulipa (Ranwala and Miller 2009), Rosa (Gholami et al. 2011) and Lilium flowers (van Doorn and Hanb 2011). Sugars supply materials for building structures for the plant organs and contribute to cell wall synthesis, resulting in an increased vase life of flowers (Ichimura 1998). Sugar also reduces ethylene production by the petals of cut flowers, as found in cut Dianthus, which, when treated with sucrose, significantly decreased the ethylene production of petals (Verlinden and Garcia 2004). Both mono- and disaccharides have been found in flower cells of many types of cut flowers, such as Sandersonia aurantiaca (Eason et al. 1997), Rosa (Ichimura et al. 1997), Petunia (O'Donoghue et al. 2008) and Antirrhinum majus L. (Asrar 2012) (Tab. 1). Among the different types of sugar, sucrose has been commonly used commercially to prolong the longevity of cut flowers (Pun and Ichimura 2003). Sucrose is a main component in commercial vase solutions, such as Chrysal (Chrysal, Naarden, The Netherlands), providing a carbon source for flowers and shown to have a positive effect in extending the vase life in cut Dendrobium 'Kao Sanan', 'Lovely Pink' and 'Suree Peach' (Obsuwan et al. 2013). In higher plants, the hydrolysis of sucrose provides monosaccharides of glucose and fructose, as was the case in cut Rosa (Yamada et al. 2007), which are then further metabolized by acid invertase ( $\beta$-fructosidase, EC 3.2.1.26) present (in a soluble form) in the vacuoles of the petals (Ap Ree 1974, Kaltaler and Steponkus 1974, Roitsch and Gonzalez 2004).

8-hydroxyquinoline sulphate (HQS) combined with sucrose was found to be very effective in increasing the vase life and reducing respiration rate and physiological weight loss in Dendrobium
(Dineshbabu et al. 2002) and Gladiolus (Beura et al. 2011). The biocide HQS is a very important germicide in the preservatives used by the floral industry (Nowak and Rudnicki 1990) to keep cut flowers fresh over extended periods. Biocides reduce the entry of bacteria and fungi, and help to prevent the blockage of xylem vessels by air and microorganisms that cause xylem occlusion (Hardenburg 1968). The use of HQS for preventing microbial growth results in an increase in water uptake by cut flowers (Reddy et al. 1996).

The effects of the types and concentrations of sugar on the vase life of cultivars have also been found to vary. While sucrose at a concentration of 146.2 mM delayed ethylene production in Dianthus caryophyllus 'White Sim', fructose, glucose and maltose used at the same concentration did not delay ethylene production (Verlinden and Garcia 2004). Similarly, combinations of glucose and aminooxyacetic acid (AOA) resulted in a longer vase life of flowers of Dendrobium compared with sucrose plus AOA used at the same rate (Rattanawisalanon et al. 2003). The response of the vase life of flowers to sucrose concentrations also varied in cut Antirrhinum, whose flower vase life increased with increasing sucrose concentration from 7.31 to $14.6 \mathrm{mM}$, reaching a maximum at the concentration of $14.6 \mathrm{mM}$, and then decreased with increasing concentrations to $29.2 \mathrm{mM}$, when used in combination with $200 \mathrm{mg} \mathrm{L}^{-1} \mathrm{HQS}$ (Ichimura and Hisamatsu 1999).

The vase life of flowers of Chamelaucium uncinatum 'Alba' was extended with the presence of sucrose at a concetration of $58.5 \mathrm{mM}$ in the vase water, but this concentration of sucrose damaged the leaves (Joyce and Jones 1992). Treatment with $58.5 \mathrm{mM}$ sucrose plus $200 \mathrm{mg} \mathrm{L}^{-1} \mathrm{HQS}$ significantly increased the vase life of $C$. uncinatum cultivars (Joyce 1988). Increasing sucrose concentrations up to $146.2 \mathrm{mM}$, combined with $200 \mathrm{mg} \mathrm{L}^{-1} \mathrm{HQS}$,

Table 1. Literature references on the presence of mono- and disaccharides in the flower cells of cut flowers

\begin{tabular}{|c|c|c|c|c|c|}
\hline \multirow{3}{*}{ Cultivar } & \multirow{3}{*}{ Reference } & \multicolumn{4}{|c|}{ Type of sugar } \\
\hline & & \multicolumn{3}{|c|}{ Monosaccharide } & \multirow{2}{*}{$\frac{\text { Disaccharide }}{\text { Sucrose }}$} \\
\hline & & Fructose & Glucose & Galactose & \\
\hline Rosa Carl Red & Ichimura et al. 1997 & $\sqrt{ }$ & $\sqrt{ }$ & & $\sqrt{ }$ \\
\hline Rosa Rote Rose & Ichimura et al. 1997 & $\sqrt{ }$ & $\sqrt{ }$ & & $\sqrt{ }$ \\
\hline Rosa Sonia & Ichimura et al. 1997 & $\sqrt{ }$ & $\sqrt{ }$ & & $\sqrt{ }$ \\
\hline Sandersonia tubers & Eason et al. 1997 & $\sqrt{ }$ & $\sqrt{ }$ & & $\sqrt{ }$ \\
\hline Petunia Mitchell & O’Donoghue et al. 2008 & & $\sqrt{ }$ & $\sqrt{ }$ & \\
\hline Antirrhinum majus Yellow Butterfly & Asrar 2012 & $\sqrt{ }$ & $\sqrt{ }$ & & \\
\hline
\end{tabular}

Note: $\sqrt{ }$ means similar to the previous one 
decreased the vase life of flowers and leaves of C. uncinatum 'Purple Pride' (Joyce 1988). However, there has been no extensive research on the effects of different types and concentrations of sugar, and the effects of the interaction between sucrose and HQS concentrations on the vase life of cultivars of different waxflower species. The aim of this study was to evaluate the effect of different types and concentrations of sugar on the vase life of a range of waxflower cultivars. Also, an effective vase solution with a combination of HQS and sucrose concentrations was determined.

\section{MATERIAL AND METHODS}

\section{Plant material}

Flowering stems of Chamelaucium uncinatum (Myrtaceae) 'Purple Pride', 'Alba' and 'Mullering Brook', C. megalopetalum $\times$ C. uncinatum 'Bridal Pearl', 'Denmark Pearl', 'Laura Mae Pearl' and 'Crystal Pearl', C. uncinatum $\times$ C. megalopetalum 'WX87', C. sp. Gingin $\times(C$. uncinatum $\times C$. uncinatum) 'WX97', C. floriferum $\times$ C. uncinatum 'Lady Stephanie' and (C. uncinatum $\times$ Verticordia grandis $\times$ Verticordia grandis 'WX73' were harvested early in the morning from July to October 2012, from mature (5-year-old) bushes cultivated under irrigation and fertigation (Seaton and Poulish 2010) at Medina Research Station $\left(32^{\circ} 13^{\prime} 18^{\prime \prime S}\right.$, $\left.115^{\circ} 38^{\prime} 50^{\prime \prime} \mathrm{E}\right)$ of the Department of Agriculture and Food Western Australia (DAFWA). Flowering stems of approximately $60 \mathrm{~cm}$ in length with 50 $70 \%$ of the flowers open were cut from an average of five bushes, and the cut ends of the stems were immediately placed upright in buckets of clean water, and then transported by an air-conditioned vehicle at approximately $20^{\circ} \mathrm{C}$ to the postharvest laboratory of DAFWA in South Perth, the journey taking about 35 minutes (Seaton et al. 2010, Seaton and Joyce 1996). In the laboratory, cut stems were randomly chosen and cut shorter under water to a length of $30 \mathrm{~cm}$ (measured from the cut end to the most extreme opened-flower) for vase life assesement.

\section{Experimental design}

\section{Experiment 1: Sugar type treatments}

Two disaccharides (sucrose and maltose) and three monosaccharides (glucose, fructose and galactose) were all at a concentration of $58.5 \mathrm{mM}$ and supplemented with $200 \mathrm{mg} \mathrm{L}^{-1} \mathrm{HQS}$. The vase life of flowers and leaves in the different sugars was compared for 'Bridal Pearl', 'Denmark Pearl',
'Laura Mae Pearl', 'Crystal Pearl', 'WX87', 'WX97', 'Lady Stephanie', 'WX73', 'Mullering Brook' and 'Purple Pride' with the vase life in deionized water (DI) used as a control. The experiment was arranged in a completely randomized design, and each treatment was repeated eight times with 1 stem per replication.

\section{Experiment 2: Sucrose concentrations}

A two-factor experiment was conducted to test the effect of different sucrose concentrations on vase life for the different cultivars. The sucrose concentration factor included 0.0, 14.6, 29.2, 58.5 and $117.0 \mathrm{mM}$ sucrose prepared by dissolving 0,5 , 10,20 and $40 \mathrm{~g}$ of table sugar in $1 \mathrm{~L}$ of deionized water. The cultivar factor included the cultivars 'Bridal Pearl', 'Denmark Pearl', 'Laura Mae Pearl', 'WX97', 'Lady Stephanie', 'WX73', 'Mullering Brook' and 'Purple Pride'. HQS at a concentration of $200 \mathrm{mg} \mathrm{L}^{-1}$ was added to the vase water containing sucrose. This completely randomized experiment was designed with each treatment repeated eight times with 1 stem per replication.

\section{Experiment 3: Sucrose vs. HQS}

A factorial experiment was conducted to test the effect of the combination of sucrose at concentrations of $14.6,29.2,58.5$ and $117.0 \mathrm{mM}$ and HQS at concentrations of 50, 100, 200 and $400 \mathrm{mg} \mathrm{L}^{-1}$ on the vase life of the cultivar 'Alba'. Deionized water was used as a control. The experiment was arranged in a completely randomized design with eight replications for each treatment and 1 stem per replication.

\section{Experimental conditions}

Vase life was assessed in a controlled-room at 20 $\pm 2^{\circ} \mathrm{C}, 60 \pm 10 \% \mathrm{RH}$, with a $12 \mathrm{~h}$ photoperiod. The light flux densities were $8 \mu \mathrm{mol} \mathrm{m} \mathrm{m}^{-2} \mathrm{~s}^{-2}$. In each experiment, all stems were individually placed in $250 \mathrm{~mL}$ plastic vases, each containing one of the above vase solutions.

\section{Measurements of the vase life of flowers and leaves}

The vase life of flowers was determined when $50 \%$ of opened flowers were fully closed or showed damage to the petals. For the genotypes whose flowers had dropped before closing, the end of vase life was determined when $50 \%$ of opened flowers had dropped. The vase life of leaves was determined when $50 \%$ of the leaves were fully desiccated or yellow. 
Assessment of the relationship between the vase life of flowers and the number of days when stem fresh weight was above or below the initial stem fresh weight

The number of days when stem fresh weight was above the initial stem fresh weight was recorded as a period of time from the day the stems had been placed in the vase solutions to the day when their fresh weight equalled the initial stem fresh weight. The number of days when stem fresh weight was below the initial stem fresh weight was determined as the vase life of flowers (days) minus the number of days when stem fresh weight was above the initial stem fresh weight.

\section{Statistical analysis}

The vase life of flowers and leaves resulting from treatment effects (sugar type $\times$ genotype, sucrose concentration $\times$ genotype, and the factorial treatment of sucrose concentration $\times$ HQS concentration) was analyzed with 2-way ANOVA using the statistical package Genstat XV (Lawes Agricultural Trust, Rothamsted Experimental station, UK). Treatment means were compared by LSD at $p<0.05$ and the means $( \pm \mathrm{SE})$ were shown as appropriate. Where possible, comparisons between the means were made using Duncan's Multiple Range Test.

\section{RESULTS}

\section{Sugar type treatments}

The flower vase life of all the cultivars was significantly $(p<0.05)$ extended $(1.3$-fold $)$ in the vase solutions containing $58.5 \mathrm{mM}$ sugar coupled with $200 \mathrm{mg} \mathrm{L}^{-1} \mathrm{HQS}$, compared with that of the controls (Tab. 2). The flower vase life of almost all the cultivars treated with sucrose was not significantly $(p<0.05)$ different from those treated with fructose or glucose, except for 'Laura Mae Pearl', whose vase life in fructose was significantly $(p<0.05)$ greater $(1.1$-fold $)$ than that in sucrose. For sucrose, fructose and glucose, flower vase life increased on average 1.4-fold, and 1.3-fold for maltose and 1.2-fold for galactose compared with the DI controls (Tab. 2). However, in terms of flower vase life the response of individual cultivars to the types of sugar varied. The flower vase life of cultivars was significantly $(p<0.05)$ extended (from 1.2 to 1.8 -fold) by the addition of sugars, except for 'WX73' in sucrose, 'Crystal Pearl', 'WX73' and 'WX97' in maltose, 'Purple Pride' and 'WX73' in glucose, 'Lady Stephanie', 'Purple Pride', 'WX87' and 'WX73' in galactose, and 'Mullering Brook' in all types of sugar, whose flower vase life was similar to that in the control (Tab. 2).

The vase life of leaves of all the cultivars was significantly $(p<0.05)$ decreased (by $25.8 \%)$ by the addition of $58.5 \mathrm{mM}$ sugar to the vase water containing $200 \mathrm{mg} \mathrm{L}^{-1} \mathrm{HQS}$, compared with the vase life in the controls (Tab. 3). For sucrose, fructose and glucose, vase life decreased by an average of $30 \%$, and by $50 \%$ for maltose and galactose, compared with the control (Tab. 3). In terms of the vase life of leaves the response of individual cultivars to the different types of sugar varied. The leaf vase life of 'Lady Stephanie' significantly $(p<0.05)$ increased (on average 1.3-fold) in all the

Table 2. Effect of different types of sugar in combination with $200 \mathrm{mg} \mathrm{L}^{-1} \mathrm{HQS}$ on the vase life of flowers

\begin{tabular}{|c|c|c|c|c|c|c|c|}
\hline \multirow{2}{*}{ Cultivar } & \multicolumn{6}{|c|}{ Vase life of flowers (days) } & \multirow{2}{*}{$\begin{array}{c}\text { Overall } \\
\text { mean vase } \\
\text { life }\end{array}$} \\
\hline & Control & Sucrose & Maltose & Glucose & Fructose & Galactose & \\
\hline Crystal Pearl & 23.9 & 33.3 & 25.3 & 31.6 & 30.8 & 31.4 & 29.4 \\
\hline Laura Mae Pearl & 21.5 & 34.9 & 34.1 & 36.3 & 38.3 & 30.9 & 32.7 \\
\hline Bridal Pearl & 18.4 & 25.0 & 28.0 & 26.1 & 27.8 & 25.1 & 25.1 \\
\hline Denmark Pearl & 15.5 & 28.4 & 25.8 & 27.3 & 27.9 & 22.4 & 24.6 \\
\hline Lady Stephanie & 15.5 & 20.8 & 18.6 & 19.0 & 23.3 & 18.0 & 19.2 \\
\hline WX87 & 14.4 & 18.1 & 17.5 & 18.5 & 18.1 & 15.9 & 17.1 \\
\hline WX73 & 13.4 & 15.4 & 12.8 & 14.9 & 17.6 & 13.1 & 14.5 \\
\hline Mullering Brook & 12.0 & 15.0 & 10.3 & 13.4 & 13.9 & 12.4 & 12.8 \\
\hline WX97 & 11.8 & 19.6 & 13.4 & 18.8 & 18.1 & 16.6 & 16.4 \\
\hline Purple Pride & 9.3 & 13.6 & 14.6 & 12.0 & 15.9 & 10.3 & 12.6 \\
\hline $\begin{array}{l}\text { Overall mean } \\
\text { of vase life }\end{array}$ & 15.6 & 22.4 & 20.0 & 21.8 & 23.2 & 19.6 & 20.4 \\
\hline
\end{tabular}

$\operatorname{LSD}(p<0.05)$ for sugar types $=0.8$ day, for cultivars $=1.0$ day, and for sugar types $\times$ cultivars $=2.4$ days by 2 -way analysis of variance 
Table 3. Effect of different types of sugar in combination with $200 \mathrm{mg} \mathrm{L}^{-1} \mathrm{HQS}$ on the vase life of leaves

\begin{tabular}{|c|c|c|c|c|c|c|c|}
\hline \multirow{2}{*}{ Cultivar } & \multicolumn{6}{|c|}{ Vase life of leaves (days) } & \multirow{2}{*}{$\begin{array}{c}\text { Overall } \\
\text { mean vase } \\
\text { life }\end{array}$} \\
\hline & Control & Sucrose & Maltose & Glucose & Fructose & Galactose & \\
\hline Crystal Pearl & 38.5 & 19.62 & 9.5 & 22.4 & 19.5 & 20.3 & 21.6 \\
\hline Laura Mae Pearl & 34.9 & 21.3 & 8.8 & 26.6 & 25.9 & 19.5 & 22.8 \\
\hline Bridal Pearl & 29.3 & 16.4 & 8.3 & 11.4 & 10.3 & 10.0 & 14.3 \\
\hline Denmark Pearl & 19.5 & 16.5 & 12.4 & 14.9 & 15.8 & 13.4 & 15.4 \\
\hline Lady Stephanie & 18.5 & 24.6 & 23.3 & 20.9 & 27.1 & 22.1 & 22.8 \\
\hline WX87 & 23.8 & 20.1 & 23.0 & 21.8 & 20.6 & 18.3 & 21.3 \\
\hline WX73 & 19.1 & 13.3 & 7.0 & 12.9 & 16.1 & 12.4 & 13.5 \\
\hline Mullering Brook & 9.9 & 11.5 & 7.5 & 10.5 & 10.3 & 10.5 & 10.0 \\
\hline WX97 & 17.4 & 11.9 & 7.8 & 14.4 & 10.6 & 11.8 & 12.3 \\
\hline Purple Pride & 13.8 & 13.4 & 13.5 & 12.9 & 14.1 & 12.3 & 13.3 \\
\hline $\begin{array}{l}\text { Overall mean } \\
\text { of vase life }\end{array}$ & 22.5 & 16.9 & 12.1 & 16.9 & 16.6 & 15.1 & 16.7 \\
\hline
\end{tabular}

LSD $(p<0.05)$ for sugar types $=1.3$ days, for cultivars $=1.7$ days, and for sugar types $\times$ cultivars $=4.1$ days by 2 -way analysis of variance

sugar types, and the leaf vase life of the cultivars Purple Pride, Mullering Brook and WX87 in all types of sugar, 'Denmark Pearl' in sucrose and fructose, and that of 'WX97' in glucose was similar to the vase life in the controls (Tab. 3). On the other hand, the vase life of leaves of the other cultivars significantly $(p<0.05)$ decreased (by half) in the vase solutions containing sugars, compared with the controls (Tab. 3). The addition of sucrose significantly $(p<0.05)$ extended the leaf vase life of C. floriferum hybrid 'Lady Stephanie' 1.3-fold, and 1.1-fold for C. uncinatum cultivars, but it decreased by half the leaf vase life of the cultivars with
C. megalopetalum, C. sp. Gingin and Verticordia grandis as a parent (Tab. 3).

\section{Sucrose concentrations}

Overall, increasing sucrose concentrations increased the flower vase life of six cultivars, except that of 'Laura Mae Pearl' and 'Mullering Brook' (Fig. 1A). However, in terms of flower vase life the response to sucrose concentrations depended on the cultivar. The vase life of 'Laura Mae Pearl' was significantly $(p<0.05)$ extended (1.7-fold) at a sucrose concentration of $29.2 \mathrm{mM}$, compared with that in water. At a concentration of
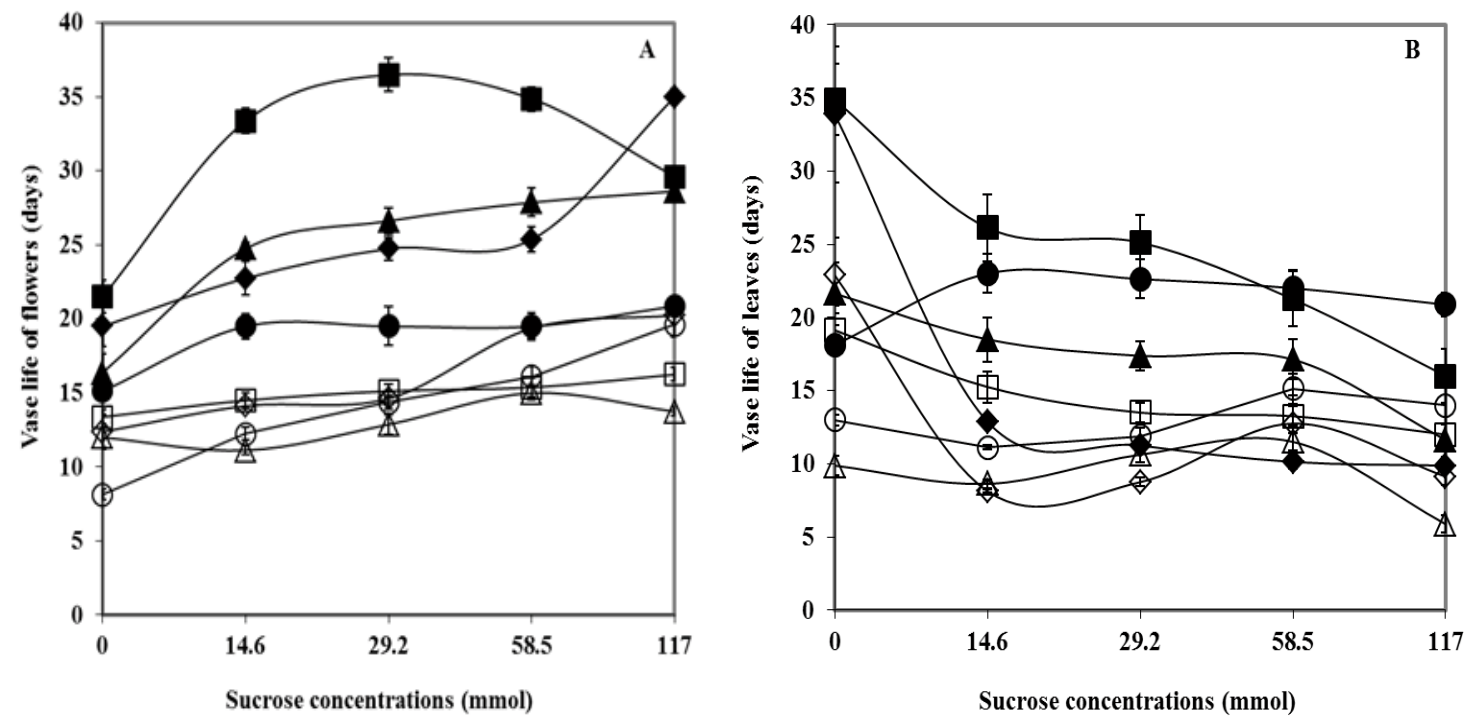

Figure 1. Vase life of flowers (Panel A) and leaves (Panel B) of 'Laura Mae Pearl' ( $\mathbf{\square})$, 'Bridal Pearl' ( $\downarrow)$, 'Denmark

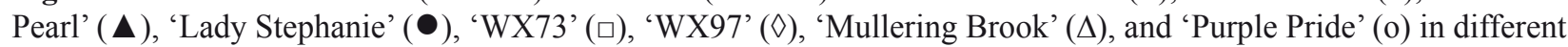
sucrose concentrations supplemented with $200 \mathrm{mg} \mathrm{L}^{-1} \mathrm{HQS}$, and in deionized water. LSD $(p<0.05)$ for flowers $=2.2$ days and for leaves $=4.0$ days by 2 -way analysis of variance, $n=8$. Vertical bars are standard errors of means 

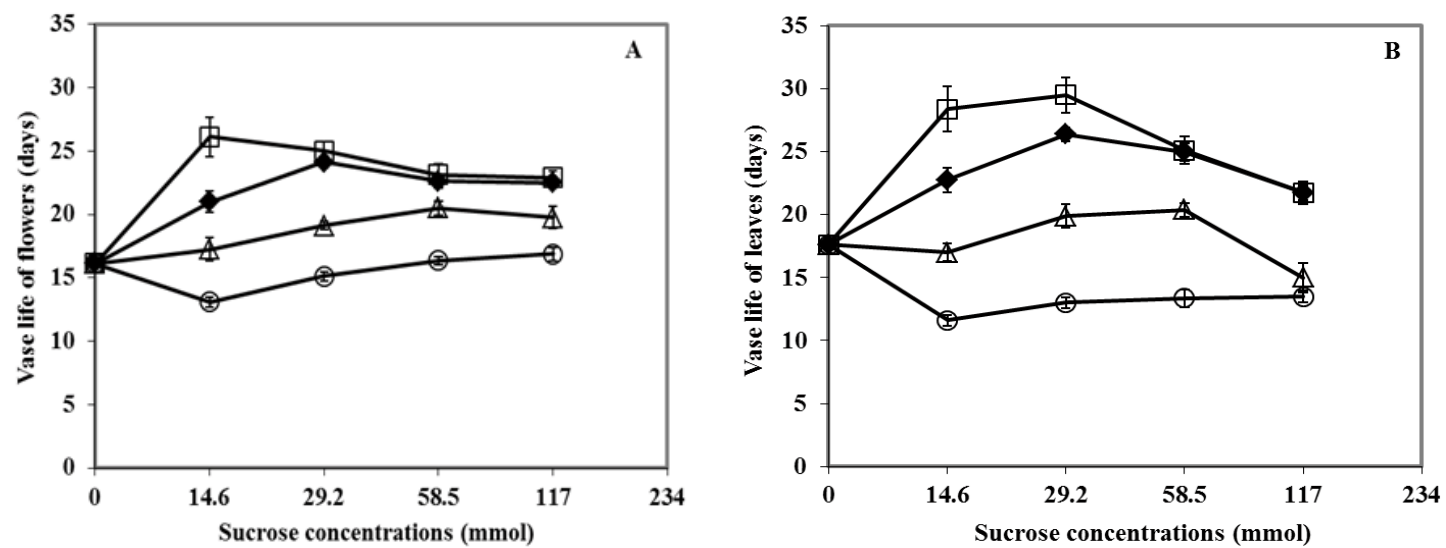

Figure 2. Effect on the vase life of flowers (Panel A) and leaves (Panel B) of C. uncinatum 'Alba' treated with 14.6, 29.2, 58.5 or $117.0 \mathrm{mmol}$ sucrose in combination with $50(\square), 100(\diamond), 200(\Delta)$ or 400 (o) mg L'-1 HQS. Zero concentration of sucrose on the graphs indicates flower stems held in deionized water. Vertical bars are standard errors of means. $\operatorname{LSD}(p<0.05)$ for flowers $=2.0$ days and for leaves $=2.6$ days, $\mathrm{n}=8$

$58.5 \mathrm{mM}$, 'Mullering Brook' showed the greatest response to sucrose, where its flower vase life reached a maximum, which was a 1.3 -fold increase, while the other cultivars continued to extend their lives with higher concentrations, with 'Bridal Pearl' and 'Purple Pride' increasing 1.8-fold and 1.6-fold, respectively, in $117 \mathrm{mM}$ compared with the control (Fig. 1A). The cultivar WX73 did not respond to the increasing sucrose concentration compared with the control (Fig. 1A).

The vase life of leaves of all the cultivars tested, except for 'Lady Stephanie', 'Purple Pride' and 'WX97', decreased with increasing sucrose concentrations. The leaf vase life of 'Lady Stephanie' was significantly $(p<0.05)$ increased (1.3-fold) to a maximum at the concentration of $14.6 \mathrm{mM}$, compared with that in the control. The leaf vase life of 'Mullering Brook' in sucrose concentrations from 14.6 to $58.5 \mathrm{mM}$ was similar to that in the DI controls and lower in $117 \mathrm{mM}$ sucrose, compared with that in the DI control. The leaf vase life of $C$. uncinatum cultivars was significantly $(p<0.05)$ increased $(1.2$-fold $)$ at the concentration of $58.5 \mathrm{mM}$, and was similar to that in the control when being treated with $29.2 \mathrm{mM}$ sucrose. The lower concentration of $14.6 \mathrm{mM}$ and the higher concentration of $117 \mathrm{mM}$ significantly $(p<0.05)$ decreased leaf vase life by $13.5 \%$ and $16.4 \%$ respectively. By comparison, the vase life of leaves of the remaining cultivars was decreased by $37 \%$ to $54 \%$ in the vase solutions containing sucrose, compared with the control (Fig. 1B).

\section{Sucrose vs. HQS concentrations}

The maximum vase life of the cultivar Alba was obtained with a low concentration of sucrose in combination with a low concentration of HQS (Figs 2A and 2B). The vase life of the flowers of 'Alba' was significantly $(p<0.05)$ extended (1.6-fold) to a maximum in the vase solution of

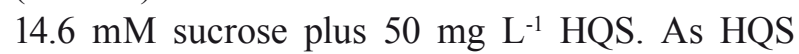
concentrations increased, the maximum vase life of 'Alba' flowers decreased and occurred at high sucrose concentrations, with the maximum vase life decreasing by $35 \%$ in $117 \mathrm{mM}$ sucrose plus $400 \mathrm{mg} \mathrm{L}^{-1} \mathrm{HQS}$ compared with the vase solution of $14.6 \mathrm{mM}$ sucrose plus $50 \mathrm{mg} \mathrm{L}^{-1} \mathrm{HQS}$ (Fig. 2A). The vase life of flowers in increasing sucrose concentrations could not be improved by increasing HQS concentrations, with a $26 \%$ decrease in vase life occurring in $117 \mathrm{mM}$ sucrose in $400 \mathrm{mg} \mathrm{L}^{-1}$ HQS compared with $50 \mathrm{mg} \mathrm{L}^{-1} \mathrm{HQS}$ (Fig. 2A).

The vase life of leaves was significantly $(p<0.05)$ extended (1.7-fold) to a maximum in the vase solution of $29.2 \mathrm{mM}$ sucrose plus $50 \mathrm{mg}$ $\mathrm{L}^{-1} \mathrm{HQS}$ (Fig. 2B). The maximum vase life at 29.2 $\mathrm{mM}$ sucrose plus $50 \mathrm{mg} \mathrm{L}^{-1} \mathrm{HQS}$ was significantly $(p<0.05)$ higher $(1.5$-fold) compared with the vase life in $58.5 \mathrm{mM}$ sucrose plus $200 \mathrm{mg} \mathrm{L}^{-1} \mathrm{HQS}$ (Fig. 2B). The vase life of leaves in increasing sucrose concentrations could not be improved by increasing HQS concentrations, with a $40 \%$ decrease in vase life occurring in $117 \mathrm{mM}$ sucrose in $400 \mathrm{mg} \mathrm{L}^{-1} \mathrm{HQS}$ compared with $50 \mathrm{mg} \mathrm{L}^{-1} \mathrm{HQS}$ (Fig. 2B).

\section{Relationship between the vase life of flowers and the number of days when stem fresh weight was above or below the initial stem weight of cultivars in different types of sugar}

The long vase life of cultivars in sugars had a higher number of days when stem fresh weight was above 


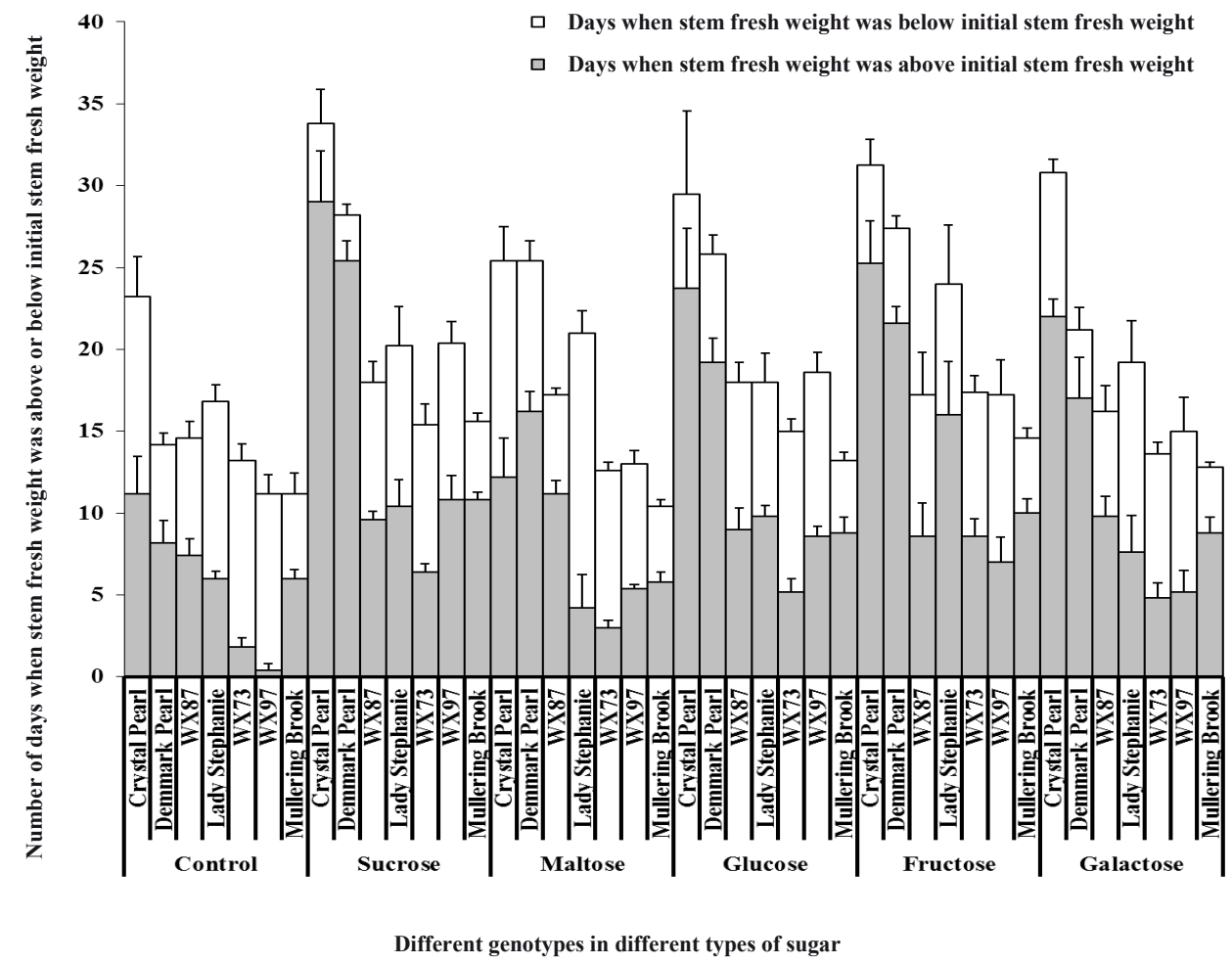

Figure 3. Relationship between the vase life of flowers and the number of days when stem fresh weight was above or below the initial stem fresh weight for different cultivars in $58.5 \mathrm{mmol}$ of sucrose, maltose, glucose, fructose and galactose supplemented with $200 \mathrm{mg} \mathrm{L}^{-1} \mathrm{HQS}$. DI water was used as a control. Vertical bars are standard errors of means, $\mathrm{n}=5$

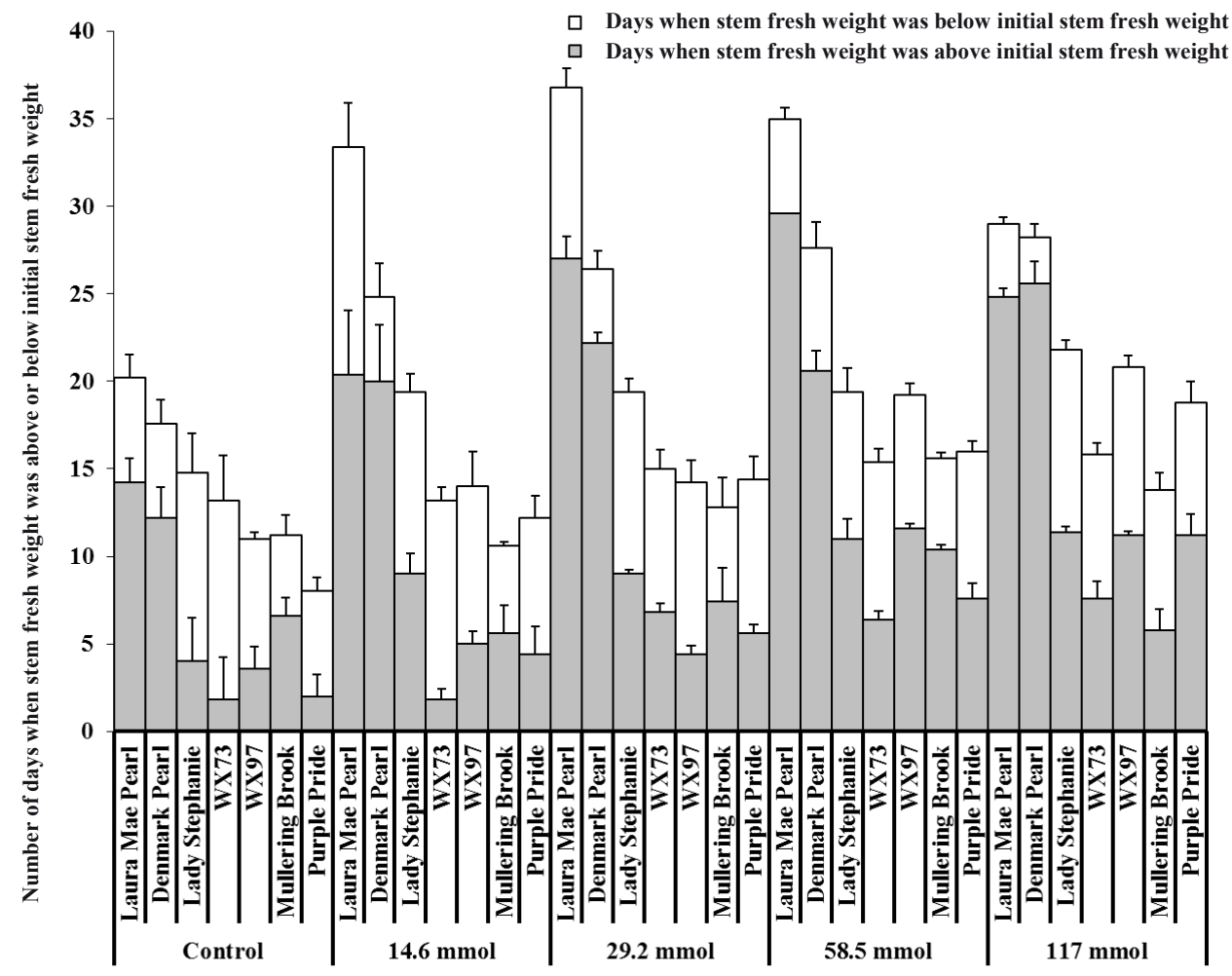

Different genotypes in different types of sugar

Figure 4. Relationship between the vase life of flowers and the number of days when stem fresh weight was above or below the initial stem fresh weight for different cultivars in different sucrose concentrations supplemented with $200 \mathrm{mg} \mathrm{L}^{-1} \mathrm{HQS}$. DI water was used as a control. Vertical bars are standard errors of means, $\mathrm{n}=5$ 
the initial stem fresh weight (DFWA) compared with the number of days when stem fresh weight was below the initial stem fresh weight (DFWB) (Fig. 3). DFWA of cultivars in all the types of sugar was higher (2.0-fold) than that in the controls. Overall for the cultivars, DFWA for sucrose, fructose or glucose was $108 \%, 85.2 \%$ or $51.3 \%$ higher than DFWB, respectively, while DFWA for galactose was $40.3 \%$ higher than DFWB. By contrast, DFWA for maltose and the control was $13.4 \%$ and $35.3 \%$ lower than DFWB, respectively. DFWA of the cultivars with C. megalopetalum as a parent and C. uncinatum 'Mullering Brook' in the vase solutions was $116.3 \%$ and $81.9 \%$ greater than DFWB, while DFWA of the C. floriferum hybrid 'Lady Stephanie', the C. sp. Gingin hybrid 'WX97' and the Verticordia grandis hybrid 'WX73' was $17.2 \%, 48.1 \%$ and $35.6 \%$ lower than DFWB, respectively (Fig. 3).

\section{Relationship between the vase life of flowers and the number of days when stem fresh weight was above or below the initial stem weight of cultivars in different concentrations of sucrose}

The vase life of flowers of cultivars in different concentrations of sucrose increased with increasing DFWA over DFWB (Fig. 4). DFWA of cultivars in all the sucrose concentrations was higher (with a 2.0-fold increase) than that in the control. DFWA of cultivars in 58.5 and $117 \mathrm{~m} \mathrm{~mol} \mathrm{~L}^{-1}$ was $90.6 \%$ and $92.9 \%$ greater than DFWB, respectively, while DFWA of cultivars in 29.2 and $14.6 \mathrm{mM}$ was $60.9 \%$ and $18.7 \%$ higher than DFWB, respectively. By contrast, DFWA of cultivars in the control was $14.0 \%$ lower than DFWB (Fig. 4).

\section{DISCUSSION}

The increase in the vase life of flowers achieved by supplying sucrose and HQS was consistent with the results obtained for $C$. uncinatum 'Purple Pride' (Joyce 1988). It was also consistent with sugar providing a carbohydrate source for the flower (Ichimura and Suto 1999). Increased vase life of cut flowers by sugar application has been attributed to the increased water uptake by the flowers through increasing the osmotic concentration of the florets and leaves (Pun and Ichimura 2003). In waxflower, sugar was most effective when applied to vase solutions in combination with a biocide, such as HQS, to prevent the growth of microorganisms in xylem vessels and maintain water uptake, thus prolonging the longevity of cut flowers (Asrar 2012), although HQS can become toxic.

The greater response of waxflower to sucrose, glucose and fructose is consistent with the findings in cut Rosa, where fructose, glucose and sucrose were the main soluble carbohydrates decreasing slowly during the vase life (Ichimura et al. 1999). Decreased sucrose conversion to a respirable carbohydrate occurs when there is loss of sucrose synthase and invertase activities (Yamada et al. 2007, Kumar et al. 2008). The lower vase life response to maltose and galactose is associated with the fact that they are rare types of sugar in flowers (Tab. 1) and may not be as readily respired as sucrose, and therefore are less effective in increasing the vase life of waxflower. The increase in vase life in vase solutions containing fructose or glucose may be due to the flower cells being supplied with an increased respiratory substrate to maintain stem water balance and stem fresh weight above the initial stem fresh weight for a longer time when compared with maltose or galactose. The way in which different sugar types affect the vase life of flowers is unclear. However, a study on Petunia 'Mitchell' by O'Donoghue et al. (2008) showed that the galactose content in petals decreased sharply over 2.0 days after flower opening, whereas the amounts of other sugars showed little change over that time. This suggested that the loss of galactose might also affect the vase life of flowers. Variation in genotype postharvest response to sucrose was reported in Protea 'Sylvia', whose vase life did not improve with a sucrose pulse at $584.8 \mathrm{mM}$ (Stephens et al. 2011), while a $584.8 \mathrm{mM}$ sucrose pulse $\left(24 \mathrm{~h}, 25^{\circ} \mathrm{C}\right)$ reduced leaf blackening in Protea neriifolia $\mathrm{R}$. Br. and increased the vase life of flowers (McConchie and Lang 1993).

Increasing the concentration of sucrose resulted in an increase in the supplied carbohydrate source (Nichols 1973) and osmosis concentration (Pun and Ichimura 2003), and in increased flower vase life of waxflower, confirming the result obtained for C. uncinatum cultivars (Joyce 1988). Competition for sugar between flower-buds, opening-flowers and older flowers shortened the vase life of flowers of Lilium (van der Meulen-Muisers et al. 1995). The flowers of 'Purple Pride' and the cultivars with C. megalopetalum as a parent are larger than the flowers of the remaining cultivars (Macnish et al. 2004), which may have resulted in a higher demand for carbohydrates as indicated by the shorter vase lives in our study. Increasing sucrose concentrations may have satisfied the requirement of these cultivars 
for carbohydrates and consequently increased the vase life of flowers. The decrease in the vase life of leaves in increasing sucrose concentrations could have been caused by osmotic stress in the leaves due to the use of high sugar concentrations. Joyce (1988) reported that sucrose at a concentration of $146.2 \mathrm{mM}$ in combination with $200 \mathrm{mg} \mathrm{L}^{-1} \mathrm{HQS}$ desiccated the leaves of $C$. uncinatum cultivars through osmotic stress. However, in this study a $40 \%$ lower sucrose concentration of $58.5 \mathrm{mmol}$ damaged the leaves of almost all the cultivars, except for 'Lady Stephanie' and the cultivars of $C$. uncinatum (Fig. 1B). The leaves of these cultivars may not have been damaged by sugar, indicating that those leaves did not take up as much sugar as the leaves of stressed cultivars. The vase life response of cultivars to glucose or fructose concentrations was also similar to the vase life response of cultivars to sucrose concentrations (data not shown).

Increasing the concentration of sucrose in combination with higher concentrations of HQS increased the vase life of 'Alba' (Fig. 2A). The response of the cultivar Alba to sucrose may indicate a different response to that found in Gladiolus, where lower concentrations prolonged the vase life of florets by increasing water uptake, whereas higher concentrations seemed to impede water uptake (Bravdo et al. 1974). Sucrose in combination with biocides has become an important preservative for several floral cut flowers (Pun and Ichimura 2003). Application of HQS, an antimicrobial agent (Ketsa et al. 1995), increased water uptake and fresh weight, and consequently the vase life of cut Rosa (Ichimura et al. 1999). HQS coupled with sucrose increased flower quality, water uptake, fresh weight, flower freshness and reduced respiration rate and physiological weight loss in Dendrobium (Dineshbabu et al. 2002) and Gladiolus (Beura et al. 2011). However, HQS at high concentrations can become toxic and decreases the vase life of 'Alba'. The optimal concentrations of sucrose and HQS for increasing the vase life of 'Alba' were far below those reported for 'Purple Pride' (Joyce 1988).

\section{CONCLUSIONS}

1. Critical levels of sugars were found for a range of cultivars to be from 14.6 to $29.2 \mathrm{mM}$ in combination with low HQS levels at 50 to 100 $\mathrm{mg} \mathrm{L}^{-1}$, and this depended on the type of sugar.

2. Fructose, glucose and sucrose were the most effective sugars in increasing the vase life of waxflower as compared to galactose.
3. The sugar concentration that improved the vase life of both flowers and leaves was from 14.6 to $29.2 \mathrm{mM}$.

4. HQS at $200 \mathrm{mg} \mathrm{L}^{-1}$ can become toxic, but a quarter of this amount extended vase life. The vase life of flowers of cultivars increased with increasing number of days when stem fresh weight was above the initial stem fresh weight.

\section{ACKNOWLEDGEMENTS}

Technical support from George Morris and Chris McMullan (DAFWA) in collecting samples is acknowledged.

\section{FUNDING}

This work was funded by the Australian Government Overseas Aid Program (AusAID) in 2011 and supported by the Department of Agriculture and Food Western Australia (DAFWA) with its facilities.

\section{AUTHOR CONTRIBUTIONS}

All of the authors contributed extensively to the work presented in this paper. C.D.D. - conducted the research work, collected and analyzed data, and wrote the research paper; K.S. - designed the experiments, provided the samples, offered suggestions and corrected the manuscript; Z.S. offered suggestions and corrected the manuscript.

\section{CONFLICT OF INTEREST}

Authors declare no conflict of interest.

\section{REFERENCES}

Ap Ree T., 1974. MTP International Review of Science. Plant Biochemistry. Butterworths-University Park Press, London, UK.

Arrom L., MunNé-Bosch S., 2012. Sucrose accelerates flower opening and delays senescence through a hormonal effect in cut lily flowers. Plant Sci. 188: 41-47.

AsRar A.W.A., 2012. Effects of some preservative solutions on vase life and keeping quality of snapdragon (Antirrhinum majus L.) cut flowers. J. Saudi Soc. Agric. Sci. 11: 29-35.

Beura S., Ranvir S., Sing R., 2011. Effect of sucrose pulsing before storage on postharvest life of Gladiolus. J. Ornamen. Hort. 4: 91-94.

Bravdo B., Mayak S., Aravrieli Y., 1974. Sucrose and water uptake from concentrated sucrose solutions by 
gladiolus shoots and the effect of these treatments on floret life. Can. J. Bot. 52: 1271-1281.

Dineshbabu M., Jawaharlal M., Vijayakumar M., 2002. Influence of holding solutions on the postharvest life of Dendrobium hybrid Sonia. S. Indian Hort. 50: 451-457.

Eason J.R., de VRé L.A., Somerfield S.D., Heyes J.A., 1997. Physiological changes associated with Sandersonia aurantiaca flower senescence in response to sugar. Postharv. Biol. Tech. 12: 43-50.

Gholami M., Rahemi M., Rastegar S., 2011. Effect of pulse treatment with sucrose, exogenous benzyl adenine and gibberellic acid on vase life of cut rose 'Red One'. Hort. Environ. Biotechnol. 52: 482-487.

Hardenburg R.E., 1968. The commercial storage of fruits, vegetables and florist and nursery stock. United States, Department of Agriculture, Agricultural Research Sevice.

Holly W.D., 1963. Grow Keeping Quality into Your Flowers. University of Missouri, Columbia, USA.

ICHIMURA K., 1998. Improvement of postharvest life in several cut flowers by the addition of sucrose. Jap. Agric. Res. Q. 32: 257-280.

ICHimURA K., Hisamatsu T., 1999. Effects of continuous treatment with sucrose on the vase life, soluble carbohydrate concentrations, and ethylene production of cut snapdragon flowers. J. Jap. Soc. Hort. Sco. 68: 61-66.

Ichimura K., Kohata K., Koketsu M., Yamaguchi Y., Yamaguchi H., Suto K., 1997. Identification of methyl $\beta$-glucopyranoside and xylose as soluble sugar constituents in roses (Rosa hybrida L.). Bio. Biotechnol. Biochem. 61: 1734-1735.

IChimura K., KoJima K., Goto R., 1999. Effects of temperature, 8-hydroxyquinoline sulphate and sucrose on the vase life of cut rose flowers. Postharv. Biol. Tech. 15: 33-40.

Ichimura K., Suto K., 1999. Effects of the time of sucrose treatment on vase life, soluble carbohydrate concentrations and ethylene production in cut sweet pea flowers. Plant Growth Regul. 28: 177-122.

Joyce D.C., 1988. Posthavest characteristics of Geraldton wax flowers. J. Amer. Soc. Hort. Sci. 113: 738-742.

Joyce D.C., Jones P.N., 1992. Water balance of the foliage of cut Geraldton waxflower. Postharv. Biol. Tech. 2: 31-39.

Kaltaler R.E.L., Steponkus P.L., 1974. Uptake and metabolism of sucrose in cut roses. J. Amer. Soc. Hort. Sci. 99: 490-493.

Ketsa S., Piyasaengthong Y., Prathuangwong S., 1995. Mode of action of $\mathrm{AgNO}_{3}$ in maximizing vase life of Dendrobium 'Pompadour' flowers. Postharv. Biol. Tech. 5: 109-117.

Kumar N., Srivastava G.C., Dixit K., 2008. Role of sucrose synthase and invertases during petal senescence in rose (Rosa hybrida L.). J. Hort. Sci. Biotechnol. 83: 520-524.
Macnish A.J., Joyce D.C., Irving D.E., Wearing A.H., 2004. A simple sustained release device for the ethylene binding inhibitor 1-methylcyclopropene. Postharv. Biol. Tech. 32: 321-338.

McConchie R., Lang N.S., 1993. Carbohydrate metabolism and possible mechanisms of leaf blackening in Protea neriifolia under dark postharvest conditions. J. Amer. Soc. Hort. Sci. 118: 355-361.

Nichols R., 1973. Senescence of the cut carnation flower: respiration and sugar status. J. Hort. Sci. 48: 111-121.

NowaK J., Rudnicki R.M., 1990. Postharvest Handling and Storage of Cut Flower, Florist, Greens and Potted Plants. Timber Press, Portland, Oregon, USA.

O'Donoghue E.M., Somerweld S.D., Watson L.M., Brummell D.A., Hunter D.A., 2008. Galactose metabolism in cell walls of opening and senescing petunia petals. Planta 229: 709-721.

Obsuman K., Changpun W., Thongrukdee A., Chanjirakul K., Thepsithar C., 2012. Evaluation of tested vase solution compared to commercial vase solution on cut Dendrobium hybrids. Acta Hort. 970: 255-260.

Pun U.K., Ichimura K., 2003. Role of sugars in senescence and biosynthesis of ethylene in cut flowers. Jap. Agric. Res. Q. 37: 219-244.

Ranwala A.P., Miller W.B., 2009. Comparison of the dynamics of non-structural carbohydrate pools in cut tulip stems supplied with sucrose or trehalose. Postharvest Biol. Tech. 52: 91-96.

Rattanawisalanon C., Ketsa S., Van Doorn W.G., 2003. Effect of aminooxyacetic acid and sugars on the vase life of Dendrobium flowers. Postharv. Biol. Tech. 29: 93-100.

Reddy B.S., Singh K., Singh A., 1996. Effect of sucrose, citric acid and 8-hydroxyquinoline sulphate on the postharvest physiology of tuberose cv. single. Adv. Agric. Res. India 3: 161-167.

Roitsch T., Gonzalez M.C., 2004. Function and regulation of plant invertases: sweet sensations. Trends Plant Sci. 9: 606-613.

Seaton K., Joyce D.C., 1996. Effect of postharvest dipping in insecticides on the vase life of Geraldton waxflower. Aust. J. Exp. Agric. 36: 373-378.

Seaton K., Lee K., TAn B., 2010 Vase life and root propagation of Geraldton wax (Chamelaucium spp.) cut flowers treated with Glyphosate. Korean Soc. Hort. Sci. 51: 545-550.

Seaton K., Poulish N., 2010. Production of premium waxflower, Department of Agriculture and Food, Western Australia. Bulletin 4778. Available online at http://www.agric.wa.gov.au; cited on 02 Oct 2013.

Stephens I.A., Jacobs G., Holcroft D.M., 2011. Glucose prevents leaf blackening in 'Sylvia' proteas. Postharv. Biol. Tech. 23: 237-240.

van der Meulen-Muisers J., van Oeveren J., Meijkamp B., Derks F., 1995. Effect of floral bud reduction on 
individual flower longevity in Asiatic hybrid lilies. Acta Hort. 405: 46-57.

vAn Doorn W.G., 2001. Role of soluble carbohydrates in flower senescence: a survey. Acta Hort. 543: 179-183. van Doorn W.G., Hanb S.S., 2011. Postharvest quality of cut lily flowers. Postharv. Biol. Tech. 62: 1-6.

VAN STAden J., 1995. Hormonal control of carnation flower senescence. Acta Hort. 405: 232-239.

Verlinden S., Garcia J.J.V., 2004 Sucrose loading decreases ethylene responsiveness in carnation
(Dianthus caryophyllus cv. White Sim) petals. Postharv. Biol. Tech. 31: 305-312.

Yamada K., Ito M., Oyama T., NaKada M., Maesaka M., YAMAKI S., 2007. Analysis of sucrose metabolism during petal growth of cut roses. Postharv. Biol. Tech. 43: 174-177.

Received November 11, 2016; accepted March 16, 2017 